\title{
HUBUNGAN AKTIVITAS FISIK PADA IBU HAMIL DENGAN BERAT BADAN LAHIR DI KABUPATEN JENEPONTO
}

\section{THE RELATIONSHIP OF PHYSICAL ACTIVITY TO PREGNANT WOMENWITH BIRTH WEIGHT IN JENEPONTO DISTRICT}

\author{
Wina Kurnia $S^{1}$, Veni Hadju ${ }^{2}$, Masyitha Muis ${ }^{3}$ \\ ${ }^{1}$ Bagian Gizi, Fakultas Kesehatan Masyarakat, Universitas Hasanuddin \\ ${ }^{2}$ Bagian Kesehatan dan Keselamatan Kerja Universitas Hasanuddin
}

*Alamat Korespondensi: Fakultas Kesehatan Masyarakat, Universitas HasanuddinMakassar, Wina Kurnia S, SKM, Hp: 085242950013, Email :winaakurniaa92@gmail.com

\begin{abstract}
ABSTRAK
Berat badan lahir merupakan dampak dari kondisi kesehatan ibu selama kehamilan dan masih menjadi masalah kesehatan dunia khususnya di Negara berkembang. Penelitian ini bertujuan untuk mengetahui hubungan aktivitas fisik pada ibu hamil dengan berat badan lahir.Penelitian ini dilaksanakan di Kabupaten Jeneponto. Jenis penelitian yang digunakan adalah observasional dengan menggunakan desain kohort prospektif. Pengambilan sampel sebanyak 102 ibu hamil yang telah diintervensi dengan kapsul tepung dan ekstrak daun kelor serta kapsul besi-asam folat selama tiga bulan dilakukan melalui Teknik Purposive Sampling. Pengumpulan data dilakukan dengan menggunakan kuesioner aktivitas fisik dari IPAQ dan timbangan berat badan bayi. Analisis data dilakukan secara univariat dan bivariat. Dalam penelitian ini menunjukkan mayoritas responden berusia $20-35$ tahun (78\%), tingkat pendidikan SD/MI (27\%) dan berprofesi sebagai ibu rumah tangga dan petani $(58.8 \%$ dan $25.5 \%$ ) serta penghasilan perbulan yang rendah (70.6\%). Pada analisis bivariat, memperlihatkan bahwa tidak ada hubungan antara aktivitas fisik dengan berat badan lahir bayi $(\mathrm{p}=0.561)$. Berdasarkan intervensi juga tidak terlihat hubungan antara aktivitas fisik dengan berat badan lahir dengan $\mathrm{p}$ value masing-masing $\mathrm{p}=0.391, \mathrm{p}=$ $0.840, \mathrm{p}=0.644$. Setelah dikontrol dengan tingkat stres maka terlihat perbedaan yang signifikan antara stres ringan dengan aktivitas ringan dan stres berat dengan aktivitas berat $(\mathrm{p}=0.034)$. Disimpulkan bahwa hubungan aktivitas fisik dengan berat badan lahir diperberat oleh kejadian stres.
\end{abstract}

Kata Kunci:Ibu hamil, aktivitas fisik, berat badan lahir

\begin{abstract}
Birth weight is the impact of maternal health conditions during pregnancy and is still a world health problem especially in developing countries. This study aims to determine the relationship of physical activity in pregnant women and birth weight. This research was conducted in Jeneponto Regency. The type of research used was observational by using prospective cohort design. The sample were 102 pregnant women who had intervened with flour capsules, Moringa leaf extract, and folic acid-iron capsule for three months. It was done through Purposive Sampling Technique. Data were collected using a physical activity questionnaire from IPAQ and infant weight scales. Data analysis was done by using univariate and bivariate analysis. In this study showed that the majority of respondents were 20-35 years old (78\%), education level of primary school (27\%), as housewife and farmer (58.8\% and 25.5\%) and low monthly income (70.6\%). In bivariate analysis, it showed that there was no correlation between physical activity and infant birth weight $(p=0.561)$. Based on the intervention, it has been shown that there is also no relationship between physical activity with birth weight ( $p$ value $=0.391,0.840$ and 0.644, respectively). After controlled the stress level, there was a significant difference between mild stress with mild activity and severe stress with severe activity $(p=0.034)$. It was concluded that the association of physical activity with birth weight was exacerbated by the incidence of stress.
\end{abstract}

Keywords: Pregnant women, physical activity, birth weight 


\section{PENDAHULUAN}

Berat badan lahir merupakan dampak dari kondisi kesehatan ibu selama kehamilan. Berat bayi lahir umumnya digunakan sebagai tolak ukur kematangan dan merupakan faktor penentu kelangsungan hidup dan perkembangan anak (Gill, 2013 ; Agarwal et al., 2012). Pada tahun 2013, secara global, hampir 22 juta bayi yang baru lahir, diperkirakan $16 \%$ yang memiliki berat badan lahir rendah. Asia Selatan memiliki insiden tertinggi berat badan lahir rendah, dengan satu dari empat bayi yang baru lahir (UNICEF, 2016). Estimasi regional berat bayi lahir rendah termasuk 28\% di Asia, 13\% di Afrika subSahara dan 9\% di Amerika Latin (WHO, 2014). Di Indonesia, Berdasarkan prevalensi berat badan lahir bayi $<2500$ gram sebesar 10,2\% (Riskesdas, 2013).

Bayi yang lahir dengan berat badan yang rendah berdampak negatif pada awal perkembangan, infeksi berulang, cacat perkembangan syaraf dan gangguan pendengaran, cenderung memiliki gangguan fungsi kekebalan tubuh dan meningkatkan risiko penyakit, kekurangan gizi, berkurangnya kekuatan otot, kemampuan kognitif dan IQ, menyebabkan beban emosional dan ekonomi yang berat bagi keluarga, menghasilkan biaya yang cukup besar untuk sektor kesehatan dan memaksakan beban yang signifikan pada masyarakat secara keseluruhan (WHO, 2016 ; Sharma \& Mirsha, 2013).

Berat badan lahir dipengaruhi oleh beberapa faktor seperti paritas, penyakit malaria, berat badan prahamil ibu, pertambahan berat badan ibu selama kehamilan, usia ibu, gaya hidup seperti merokok, mengonsumsi alkohol, penggunaan narkoba, adanya penyakit malaria, kondisi sosial ekonomi, stres serta tuntutan pekerjaan selama kehamilan (Villar et al., 2006; Karima dan Achadi, 2012; WHO, 2004). Hal ini memungkinkan bahwa aktivitas fisik di tempat kerja mungkin mempengaruhi hasil kehamilan (Mozurkewich et al., 2000). yang terbuat dari daun kering tidak hanya kaya akan protein, energi, garam
Pekerjaan yang membutuhkan tenaga fisik yang berat akan mengeluarkan energi yang besar pula sehingga akan mengurangi persediaan kalori untuk janin, sementara sebagian besar energi ibu telah terkuras terkuras oleh pekerjaan yang dilakukan. Kebutuhan energi yang tidak mencukupi pada ibu hamil dengan pekerjaan berat dapat menjadi salah satu faktor yang berpengaruh terhadap berat lahir bayi yang akan dilahirkan nantinya (Yuliva, dkk, 2009).

Saphiro et al., (2013) dan Lewis (2014) menyatakan bahwa faktor risiko dari peningkatan kejadian kelahiran prematur adalah stres psikologis selama kehamilan dan pada kondisi ini dapat menyebabkan defisiensi zat gizi dalam tubuh.

Dalam penelitian Dwarkanath et al., (2007) mengungkapkan bahwa berat badan lahir bayi dari ibu hamil yang juga memiliki pekerjaan berat di luar rumah selama trimester tiga adalah 181 gr lebih rendah. Takito (2005) dalam penelitiannya memperlihatkan bahwa jam kerja yang panjang, aktivitas fisik yang berat dapat menimbulkan ancaman pada kondisi pekerja yang hamil. Hasil penelitian Barus (2016) menunjukkan bahwa terdapat pengaruh antara aktivitas fisik ibu hamil terhadap berat badan lahir bayi, semakin berat aktivitas fisik yang dilakukan ibu hamil maka semakin rendah berat bayi lahir bayi tersebut. Hubungan antara aktivitas fisik ibu dengan ukuran bayi saat lahir sangat kuat untuk satu aktivitas spesifik, yaitu mengambil air, yang dianggap sebagai aktivitas berat oleh ibu di desa (Rao, 2003).

Upaya perbaikan gizi dalam mencegah terjadinya kejadian BBLR dapat dilakukan melalui intervensi zat gizi, baik makro maupun mikro kepada ibu hamil. Salah satu sumber zat gizi untuk ibu hamil adalah daun kelor (Moringa oleifera).Moringa oleifera, dalam penelitian telah menunjukkan bahwa kandungan bubuk mineral, vitamin dan serat, tetapi juga kemampuannya untuk memenuhi 
kebutuhan gizi harian untuk wanita hamil dan menyusui dengan pemberian jumlah kecil (25 g). Dengan dosis 25 gram daun M. oleifera bubuk, telah memenuhi kebutuhan ibu hamil dan menyusui seperti protein $21 \%$, kalsium $84 \%$, besi $94 \%$, vitamin C $143 \%$, vitamin A $69 \%$, magnesium 26\% (Diatta, 2001).

Berdasarkan uraian di atas, aktivitas fisik merupakan salah satu faktor terjadinya malnutrisi pada ibu hamil dimana kondisi tersebut akan berpengaruh berat badan lahir bayi. Oleh sebab itu, penelitian ini dilakukan untuk mengetahui Hubungan Aktivitas Fisik Pada Ibu Hamil Dengan Berat Badan Lahir Bayi Di Kabupaten Jeneponto.

\section{BAHAN DAN METODE}

\section{Lokasi dan Rancangan penelitian}

Penelitian ini dilakukan di wilayah enam Kecamatan di Kabupaten Jeneponto. Jenis penelitian ini adalah penelitian observasional dengan desain penelitian kohort prospektif, dimana subjek dalam penelitian ini adalah ibu hamil trimester tiga yang termasuk dalam kelompok intervensi yang menerima kapsul ekstrak daun kelor (GEK), kelompok yang menerima kapsul tepung daun kelor (GTK) dan kelompok yang menerima kapsul berisi zat besi dan asam folat (GBF) selama 3 bulan yang kemudian diikuti hingga melahirkan.

\section{Populasi dan sampel}

Populasi adalah semua ibu hamil yang termasuk dalam kelompok intervensi sebanyak 600 orang di Kabupaten Jeneponto.Sampel dalam penelitian ini sebanyak 102 orang yang diperoleh melalui metode puposive sampling yang terdiri atas 31 orang pada kelompok GTK, 28 orang pada kelompok GBF dan 43 orang kelompok GEK.

Metode pengumpulan dataPengumpulan data dilakukan dengan wawancara mencakup karakteristik sampel dan gambaran aktivitas fisik diperoleh dengan menggunakan kuesioner dari International respoden $(14.7 \%)$ dengan ANC yang kurang. Mayoritas reponden
Physical Avtivity Questionerre (IPAQ), serta pengukuran berat badan lahir bayi menggunakan baby scale dengan ketelitian $0,1 \mathrm{~kg}$.

\section{Analisis data}

Datamengenai aktivitas fisik dianalisis diukur dengan menggunakan METs(Metabolic Equivalent Task), karakteristik sampel diolah dengan menggunakan SPSS. Untuk menganalisis hubungan antara aktivitas fisik ibu hamil dengan berat badan lahir melalui analisis korelasi pearson. Sedangkan untuk mengetahui rata-rata berat badan lahir tiap kategori aktivitas digunakan analisis compare means.

\section{HASIL PENELITIAN \\ Karakteristik sampel}

Tabel 1 menampilkan karakteristik umum responden. Mayoritas responden (76.5\%) berada pada kelompok umur 20 35 Tahun. Berdasarkan tingkat pendidikan, mayoritas responden $(26.5 \%)$ merupakan tamatan SD/MI dan terdapat $6.9 \%$ responden yang ememiliki pendidikan terakhir di universitas. Dari 102 total responden, terdapat $58.8 \%$ yang bekerja sebagai ibu rumah tangga, $25.5 \%$ sebagai petani dan terdapat $3 \%$ yang bekerja sebagai guru. Sedangkan untuk pekerjaan suami, mayoritas bekerja sebagai petani (31.4\%). Berdasarkan pendapatan, sebagian besar responden termasuk dalam kategori pendapatan yang rendah $(70.3 \%)$. Mayoritas responden mempunyai paritas < 2 sebanyak 85 orang $(83.3 \%)$ dan responden dengan paritas $>2$ sebanyak 17 orang $(16.7 \%)$. Berdasarkan karateristik jarak kelahiran, responden dengan jarak kelahiran $>2$ tahun, lebih banyak yaitu 55 orang (53.9\%) dibandingkan jarak kelahiran $<2$ tahun sebanyak 8 orang $(6.9 \%)$ dan responden dengan anak pertama sebanyak 38 orang (39.2\%). Untuk karakteristik kunjungan ANC, reponden mayoritas mempunyai kunjungan ANC yang cukup yaitu sebanyak 87 orang $(85.3 \%)$ dan 15 orang mempunyai status gizi yang baik, dapat dilihat bahwa reponden yang tidak 
mengalami KEK lebih banyak yaitu 84 orang(82.4\%).

Tabel 1. Karakteristik Umum Responden

\begin{tabular}{|c|c|c|}
\hline Karakteristik & $\mathbf{n}$ & $\%$ \\
\hline \multicolumn{3}{|l|}{ Umur Ibu } \\
\hline$<20$ tahun & 12 & 11.8 \\
\hline $20-35$ Tahun & 78 & 76.5 \\
\hline$>35$ Tahun & 12 & 11.8 \\
\hline \multicolumn{3}{|l|}{ Pendidikan Ibu } \\
\hline Tidak Sekolah & 3 & 2.9 \\
\hline Tidak Tamat SD/MI & 15 & 14.7 \\
\hline $\mathrm{SD} / \mathrm{MI}$ & 27 & 26.5 \\
\hline SMP/MTs/Sederajat & 26 & 25.5 \\
\hline SMA/MA/Sederajat & 24 & 23.5 \\
\hline Universitas & 7 & 6.9 \\
\hline \multicolumn{3}{|l|}{ Pekerjaan Ibu } \\
\hline Ibu Rumah Tangga & 60 & 58.8 \\
\hline Petani & 26 & 25.5 \\
\hline Petani Rumput Laut & 6 & 5.9 \\
\hline Berternak & 1 & 1 \\
\hline Pedagang & 3 & 2.9 \\
\hline Guru & 4 & 3 \\
\hline Pegawai Swasta & 2 & 2 \\
\hline \multicolumn{3}{|l|}{ Pekerjaan Suami } \\
\hline Petani & 32 & 31.4 \\
\hline Buruh Harian & 14 & 13.7 \\
\hline Pegawai Negeri & 2 & 2 \\
\hline Pegawai Swasta & 7 & 6.9 \\
\hline Honorer & 6 & 5.9 \\
\hline Wiraswasta & 15 & 14.7 \\
\hline Nelayan & 3 & 2.9 \\
\hline Lainnya & 23 & 22.5 \\
\hline \multicolumn{3}{|l|}{ Pendapatan } \\
\hline Tinggi & 30 & 29.4 \\
\hline Rendah & 72 & 70.6 \\
\hline \multicolumn{3}{|l|}{ Paritas } \\
\hline$>2$ & 17 & 16.7 \\
\hline$<2$ & 85 & 83.3 \\
\hline \multicolumn{3}{|l|}{ Jarak Kelahiran } \\
\hline Anak Pertama & 40 & 39.2 \\
\hline$<2$ Tahun & 7 & 6.9 \\
\hline$>2$ Tahun & 55 & 53.9 \\
\hline \multicolumn{3}{|l|}{ Kunjungan ANC } \\
\hline Cukup & 87 & 85.3 \\
\hline Kurang & 15 & 14.7 \\
\hline
\end{tabular}

Sumber : Data Primer, 2017

Tabel 2 menunjukkan bahwa status gizi ibu hamil berdasarkan LILA termasuk dalam kategori tidak KEK (84\%). Berdasarkan kejadian anemia mayoritas responden juga termasuk dalam kategori normal (73\%). Untuk kategori stres kehamilan diketahui mayoritas responden tidak mengalami stres sebanyak 37 orang 
$(36,6 \%)$, stress ringan $15,8 \%$, stress sedang $24,5 \%$ dan yang mengalami stress berat sebanyak 24 orang $(23,8 \%)$.

Tabel 3 menunjukkan bahwa mayoritas responden berada pada kategori aktivitas sedang sebanyak 73 orang $(71.5 \%)$ sedangkan yang berada pada kategori berat yaitu 25 orang $(26.5 \%)$ dan ringan sebanyak 3 orang (2\%). Berdasarkan jenis intervensi untuk kelompok intervensi ekstrak daun kelor terdapat sebanyak 43 orang $(42.2 \%)$ sedangkan responden pada tepung daun kelor sebanyak 31 orang $(30.5 \%)$ dan kelompok besi folat sebanyak 28 orang (27.5\%).Sebagian besar berat badan lahir termasuk dalam kategori normal yaitu sebanyak 95 orang $(93.1 \%)$ dan terdapat 3 orang $(2.9 \%)$ yang termasuk dalam kategori berat badan lahir rendah.

Tabel 2 Distribusi Responden Berdasarkan Status Gizi, Anemia dan Stres Kehamilan

\begin{tabular}{lcc}
\hline \multicolumn{1}{c}{ Variabel } & n & \% \\
\hline Status Gizi & & 17.6 \\
KEK & 18 & 82.4 \\
Tidak KEK & 84 & \\
Status Anemia & & \\
Anemia & 29 & 28.7 \\
Tidak Anemia & 73 & 71.6 \\
Stres Kehamilan & & \\
Normal & 37 & 36,6 \\
Ringan & 16 & 15,8 \\
Sedang & 25 & 24,5 \\
Berat & 24 & 23,8 \\
Total & $\mathbf{1 0 2}$ & $\mathbf{1 0 0}$ \\
\hline
\end{tabular}

Sumber : Data Primer, 2017

Tabel 3. Distribusi Responden Berdasarkan Aktivitas Fisik, Kelompok Intervensi dan Berat Badan Lahir

\begin{tabular}{lcc}
\hline \multicolumn{1}{c}{ Variabel } & n & \% \\
\hline Aktivitas Fisik & & \\
$\quad$ Sedang & 68 & 66.7 \\
$\quad$ Berat & 34 & 33.3 \\
Kelompok Intervensi & & \\
$\quad$ Tepung Daun Kelor & 31 & 30.4 \\
$\quad$ Besi Folat & 28 & 27.5 \\
Ekstrak Daun Kelor & 43 & 42.2 \\
Berat Badan Lahir & & \\
$\quad$ Ringan & 3 & 2.9 \\
Normal & 95 & 93.1 \\
Lebih & 4 & 3.9 \\
\hline
\end{tabular}

Sumber : Data Primer, 2017

\section{Analisis bivariat}

Tabel 4 menunjukkan tidak ada hubungan yang signifikan antara aktivitas fisik ibu hamil dengan berat badan lahir, dimana nilai $\mathrm{p}=0.561$. Terdapat perbedaan rerata berat badan lahir dari ibu hamil dengan aktivitas fisik berat (3191 gr) dibandingan ibu hamil dengan aktivitas fisik sedang (3242 gr). Tabel 5 menujukkan bahwa tidak terdapat 
hubungan antara aktivitas fisik ibu hamil dengan berat badan lahir berdasarkan kelompok intervensi, baik itu intervensi tepung daun kelor, besi folat dan ektrak daun kelor dengan nilai $\mathrm{p}$ value masingmasing $\mathrm{p}=0.391, \mathrm{p}=0.840, \mathrm{p}=0.644$ serta terdapat perbedaan yang signifikan antara aktivitas fisik dengan berat lahir setelah mengontrol tingkat stres yaitu stres ringan dengan aktivitas ringan dan stres berat dengan aktivitas berat dengan nilai $\mathrm{p}$ $=0.034$.

Tabel 4. Hubungan Aktivitas Fisik Dengan Berat Badan Lahir

\begin{tabular}{lllll}
\multicolumn{1}{c}{$\begin{array}{c}\text { Aktivitas } \\
\text { Fisik }\end{array}$} & n & \% & Mean \pm SD & P Value \\
\hline Sedang & 68 & 66.7 & $3242 \pm 413$ & 0.561 \\
Berat & 34 & 33.3 & $3191 \pm 418$ & \\
\hline
\end{tabular}

Sumber : Data Primer, 2017

Tabel 5. Hubungan Aktivitas Fisik Dengan Berat Badan Lahir Berdasarkan Kelompok Intervensi dan Tingkat Stres

\begin{tabular}{|c|c|c|c|c|c|}
\hline \multicolumn{2}{|c|}{$\begin{array}{c}\text { Aktivitas Fisik Berdasarkan } \\
\text { Kelompok Intervensi }\end{array}$} & n & $\%$ & $\operatorname{Mean} \pm$ SD & P Value \\
\hline \multirow{2}{*}{$\begin{array}{l}\text { Tepung } \\
\text { Daun } \\
\text { Kelor }\end{array}$} & Sedang & 15 & 48.4 & $3346 \pm 511$ & \multirow[b]{2}{*}{0.391} \\
\hline & Berat & 16 & 51.6 & $3194 \pm 563$ & \\
\hline Besi Folat & $\begin{array}{c}\text { Sedang } \\
\text { Berat }\end{array}$ & $\begin{array}{c}21 \\
7\end{array}$ & $\begin{array}{l}75 \\
25\end{array}$ & $\begin{array}{l}3180 \pm 409 \\
3215 \pm 457\end{array}$ & 0.840 \\
\hline $\begin{array}{c}\text { Ekstrak } \\
\text { Daun } \\
\text { Kelor }\end{array}$ & $\begin{array}{c}\text { Sedang } \\
\text { Berat }\end{array}$ & $\begin{array}{l}33 \\
11\end{array}$ & $\begin{array}{l}74.4 \\
25.6 \\
\end{array}$ & $\begin{array}{l}3234 \pm 367 \\
3172 \pm 424\end{array}$ & 0.644 \\
\hline \multicolumn{2}{|c|}{$\begin{array}{c}\text { Aktivitas Fisik Berdasarkan } \\
\text { Tingkat Stres }\end{array}$} & $\mathbf{n}$ & $\%$ & Mean \pm SD & $P$ Value \\
\hline $\begin{array}{c}\text { Stres } \\
\text { Ringan }\end{array}$ & Sedang & 31 & 63.3 & $3348 \pm 459$ & \multirow{2}{*}{0.034} \\
\hline $\begin{array}{l}\text { Stres } \\
\text { Berat }\end{array}$ & Berat & 16 & 30.2 & $3115 \pm 471$ & \\
\hline
\end{tabular}

Sumber : Data Primer, 2017

\section{PEMBAHASAN}

Penelitian menunjukkan bahwa tidak terdapat hubungan antara aktivitas fisik ibu hamil dengan berat badan lahir ( $\mathrm{p}$ $=0.561)$. Begitu pula dengan hubungan antara aktivitas fisik dengan berat badan lahir berdasarkan kelompok intervensi tepung daun kelor, besi folat dan ekstrak daun kelor dengan $\mathrm{p}$ value masing-masing $\mathrm{p}=0.0 .391, \mathrm{p}=0.840, \mathrm{p}=0.644$. Meskipun tidak terdapat hubungan yang bermakna namun hasil perhitungan rerata berat badan lahir bayi pada ibu hamil dengan aktivitas fisik berat, mempunyai berat badan lahir yang lebih rendah (3191 gr) dibandingan ibu hamil dengan aktivitas fisik sedang (3242 gr).

Hal ini sejalan dengan penelitian yang dilakukan oleh Watson (2016) bahwa tidak terdapat hubungan antara aktivitas fisik dengan berat badan lahir, $p$ $=0.70$. Demikian halnya dengan penelitian yang dilakukan oleh Jukic (2012) dan Rego et al., (2016) bahwa tidak terdapat hubungan antara aktivitas fisik dengan berat badan lahir. Penelitian lain dilakukan oleh Jayakodi (2015) menyimpulkan bahwa aktivitas fisik selama kehamilan tidak berhubungan 
secara signifikan dengan outcome kehamilan.

Hasil ini tidak sejalan dengan penelitian Niedhammer et al., (2009) yang menunjukkan bahwa terdapat hubungan yang signifikan antara tuntutan kerja fisik $(\mathrm{OR}=4.65)$ dengan kelahiran prematur dan berat badan lahir rendah. Aminian et al., (2014) dalam penelitiannya juga menyimpulkan Ibu hamil dengan aktivitas fisik yang berat berdampak terhadap berat badan lahir bayi.

Beberapa penelitian telah melaporkan hasil yang bertentangan mengenai dampak dari pekerjaan ibu hamil. Berdiri, membungkuk berulangulang, menaiki tangga, dan mengangkat benda berat selama kehamilan terhadap pertumbuhan janin, kelahiran prematur dan komplikasi obstetrik lainnya (Khojasteh et al., 2015).Aktivitas fisik dapat meningkatkan aktivitas rahim (kontraksi). Wanita yang berisiko melahirkan prematur harus disarankan untuk mengurangi aktivitas pada trimester kedua dan ketiga.

Dwarkananth et al., (2007) mengungkapkan bahwa pekerjaan berat di luar rumah pada trimester manapun tidak terkait dengan berat badan lahir. Berat badan lahir bayi dari ibu hamil yang memiliki pekerjaan berat di luar rumah selama trimester tiga adalah 181 gr lebih rendah. Namun ada kecenderungan kenaikan berat badan lahir di antara wanita yang melaporkan adanya pekerjaan ringan di luar rumah pada trimester ketiga dibandingkan dengan mereka yang dilaporkan melakukan pekerjaan berat. Beberapa penelitian telah menunjukkan hubungan antara bekerja pada trimester ketiga dan kelahiran prematur dan berat badan lahir rendah. Penurunan berat badan lahir $150 \mathrm{gr}-400$ gr terjadi pada wanita yang terus bekerja di luar rumah selama trimester ketiga dibandingkan dengan mereka yang tinggal di rumah selama kehamilan (Dwarkananth, 2007).

Diketahui bahwa berat badan lahir bayi dari ibu hamil dengan aktivitas fisik berat ataupun sedang berada dalam kategori normal serta terdapat tiga kasus BBLR.Banyak faktor yang dapat mempengaruhi terjadinya BBLR seperti status gizi ibu yang dapat dilihat berdasarkan pengukuran LILA (Singh et al., 2009) dimana masih terdapat $17.6 \%$ ibu hamil yang mengalami KEK dan pertambahan berat badan yang kurang. KEK pada ibu hamil jika terjadi akan berdampak pada pertumbuhan janin di dalam kandungan ibu, dimungkinkan akan melahirkan bayi dengan Berat Badan Lahir yang Rendah (Kemenkes, 2015). Kejadian KEK pada kehamilan disebabkan oleh kurangnya asupan gizi yang mengakibatkan berkurangnya volume darah sehingga menurunkan curah jantung dan volume darah ke plasenta. Kurangnya aliran darah dalam plasenta dapat mengurangi nutrisi dari ibu ke bayi dan dapat menghambat pertumbuhan janin (Saifuddin, 2011). Diperkirakan rata-rata wanita hamil membutuhkan total 85.000 kalori tambahan selama kehamilan 40 minggu, dengan penambahan sekitar 300 kalori/hari. Pekerjaan fisik selama kehamilan juga meningkatkan kebutuhan energi. Kebutuhan energi dipengaruhi oleh beberapa faktor sehingga ada perbedaan antar individu (Keefe et al., 2008).

Selain itu, terdapat beberapa karakteristik responden yang dapat menjadi faktor yang berpengaruh terhadap berat badan lahir, seperti usia ibu hamil, anemia, paritas, pelayanan ANC serta stres kehamilan. Anemia dapat menyebabkan rendahnya nutrisi dan penurunan jumlah oksigen menuju plasenta sehingga oksigen dan nutrisi tidak dapat memenuhi kebutuhan tumbuh kembang janin dan menyebabkan pembatasan pertumbuhan janin (Allan, 2001). Selain itu, ibu hamil yang berusia 35 tahun atau lebih secara signifikan meningkatkan kejadian berat badan lahir rendah dibandingkan mereka yang berusia 20-34 tahun (Laopaiboon et al., 2014).

Dalam penelitian ini, BBLR terjadi pada ibu hamil dengan ANC yang kurang. 
Padahal telah diketahui bahwa dengan melakukan kunjungan ANC secara rutin, ibu hamil dapat memantau kesehatan diri dan janinnya. Hal ini sesuai dengan hasil penelitian yang dilakukan oleh Fosu et al., (2013) bahwa terdapat hubungan yang signifikan antara kunjungan ANC dengan berat badan lahir rendah.Diketahui bahwa bayi dengan BBLR dalam penelitian merupakan wanita dengan kehamilan pertama. Penelitian yang dilakukan oleh Andayasari dan Opitasari (2016) menunjukkan bahwa wanita nullipara memiliki risiko melahirkan bayi dengan berat badan lahir rendah $46 \%$ lebih tinggi [adjusted odds ratio (OR) $=1.46$; $\mathrm{P}=0.030]$.

Stres pada masa kehamilan juga diketahui berhubungan dengan berat badan lahir bayi. Dalam penelitian ini, diketahui terdapat hubungan antara aktivitas fisik dengan berat badan lahir diperberat dengan kejadian stres pada masa kehamilan. Sejalan dengan penelitian yang dilakukan oleh $\mathrm{Su}$ et al., (2015) dan Alonge (2012) bahwa terdapat hubungan yang signifikan antara stres pada masa kehamilan dengan berat badan lahir yang rendah. Selama terpapar stressor, keseluruhan sistem regulasi stres, yaitu sistem korteks hipotalamushipofisis-adrenal(HPA) dan sistem simpatik adrenal medullary (SAM) diaktifkan. HPA adalah salah satu sistem stres utama dalam tubuh manusia yang mengatur pelepasan glukokortikoid yaitu kortisol. sedangkan SAM, regulator penting kedua pada reaktivitas stres manusia, yaitu melepaskan katekolamin norepinefrin (NE) dan epinefrin (E).

Aktivitas fisik meningkatkan pelepasan katekolamin yang dapat menyebabkan kontraksi rahim. Selama kehamilan, tingkat katekolamin telah ditemukan meningkat pada wanita dengan stres kerja. Peningkatan katekolamin selama kehamilan menyebabkan menurunnya aliran darah pada uterus (Jukic, 2009; Ganong 2001; Rakers et al.,2015). Berbagai hormon, termasuk hormon pelepas kortikotropin (CRH), hormon pelepas adrenokortikotropin (ACTH), kortisol, dan (nor) adrenalin, dilepaskan dalam jumlah banyak ke dalam darah.Hormon ini dapat memediasi kontraksi uterus, menyebabkan persalinan prematur dan mempengaruhi berat badan lahir (Ganong, 2001; Mudler et al., 2002).

Dalam penelitian Liu (2013) lebih lanjut memaparkan bahwa mekanisme stres pada ibu hamil sebagai penyebab meningkatnya risiko berat lahir rendah adalah pelepasan katekolamin, yang dapat mengurangi perfusi uterus, yang berpotensi membatasi jumlah substrat yang dikirim ke janin. Dengan demikian, paparan katekolamin yang berkepanjangan dapat menyebabkan penurunan pertumbuhan janin. Stres yang dirasakan selama kehamilan juga dapat mempengaruhi selera makan, frekuensi makanan, dan kenaikan berat badan yang berperan penting dalam pertumbuhan janin. Stres dapat meningkatkan kadar kortisol endogen selama kehamilan, yang juga dapat menghambat pertumbuhan janin.Stres yang terjadi selama kehamilan dapat menyebabkan berpindahnya hormon kortisol dari ibu ke janin melalui plasenta dan memicu disfungsi sistem neuroendokrin pada janin (Kosinska, 2012).

\section{KESIMPULAN DAN SARAN}

Dalam penelitian ini tidak terdapat hubungan yang bermakna secara statistik antara aktivitas fisik dengan berat badan lahir baik yang diintervensi tepung daun kelor, besi folat dan ekstrak daun kelor. Namun, diketahui bahwa hubungan aktivitas fisik dengan berat badan lahir diperberat oleh kejadian stres.

\section{DAFTAR PUSTAKA}

Agarwal et al.(2012). Prevalence and determinants of "low birth weight" among institutional deliveries. Annals of Nigerian Medicine. Vol 5 | Issue 2

Alonge, Olanike. (2012). The Effect of Maternal Psychosocial Stress on 
InfantBirth Weight: A Retrospective Cohort Study. (Tesis). Drexel University School ofPublic Health

Aminian, et al.,(2014). Association between maternal work activity on birth weight and gestational age. Asian Pacific Journal of Reproduction.3(3): 200-203

Andayasari L and Opitasari C. (2016). Parity and risk of low birth weight infant in full term pregnancy. National Institute of Health Research and Development,Ministry of Health, Republic of Indonesia, Jakarta

Barus, Emi Br. (2016). Pegaruh Aktivitas Fisik dan Tingkat Kecemasan Ibu Terhadap Berat Badan Lahir Bayi Pada Ibu Hamil Trimester III Di RSUDKIA Sitti Fatimah (Tesis). Makassar. Universitas Hasanuddin.

Dwarkananth, et al., (2007). The relationship between maternal physical activityduring pregnancy and birth weight. Asia Pac J Clin Nutr, 16 (4):704-710.

Fosu, et al., 2013. Maternal Risk Factors for Low Birth Weight in a District Hospital in Ashanti Region of Ghana. Research in Obstetrics and Gynecology, 2(4): 48-54

Ganong, W. (2001). Review of Medical Physiology. McGraw-Hill. New York

Gill, et al., (2013). Birth and Developmental Correlates Of Birth Weight In A Sample Of Children With Potential Sensory Processing Disorder. BMC Pediatrics, 13:29

Jayakodi, et al., (2015). Effect of Physical Activity During Pregnancy on Birth Outcomes in Mothers Presenting at the Antenatal Clinic of De Soysa Maternity Hospital, Colombo 08. Asia Pacific Journal of Multidisciplinary Research, 3(2)

Jukic, A.M. Zaura. (2012). Factors correlated with physical activity during pregnancy and associations of physical activity with spontaneous abortion, length of gestation, and birthweight. Matern Child Health J, 16(5): 1031-1044.

Khaula dan Endang Alchadi. (2012).

Status Gizi Ibu dan Berat Badan

Lahir Bayi. Departemen Gizi

Kesehatan Masyarakat Fakultas

Kesehatan Masyarakat Universitas

Indonesia. Jurnal Kesehatan

Masyarakat Nasional Vol. 7, No. 3.

Keefe, et al., editor. (2008). Physical Activity and Exercise in Pregnancy. Humana Press.

Kementrian Kesehatan. (2013). Riset Kesehatan Dasar 2013. Jakarta. Kementrian Kesehatan RI

Khojasteh et al., (2016). The Relationship between Maternal Employment Status and Pregnancy Outcomes. Global Journal of Health Science; Vol. 8, No. 9

Kosinska, et al., (2012). Bartkowiak R, Kaczynski B, Szymusik I,Wielgos M.

Autonomous adrenocorticotropin reaction to stress stimuli in human fetus. Early Hum Dev 2012;88:197e201.

Laoapaibon M, et al., (2014). Advanced maternal age and pregnancy outcomes: a multicountry assessment. BJOG, 121 (Suppl. 1): 49-56.

Lau, Ying. (2013) The Effect of Maternal Stress and Health-Related Quality of Life on Birth Outcomes Among Macao Chinese Pregnant Women. J Perinat Neonat Nurs Volume 27 Number 1, 14-24

Lewis. (2014). Pregnancy-Specific Stress, Preterm Birth, and Gestational Age Among High-Risk Young Women : Jurnal AmericanPsychological

Association, Vol. 33, No. 9, 1033-1045

Moradi, Ghobad et al.,(2017). The Relationship between Maternal Diseases during Pregnancy and Low Birth Weight: a Nested CaseControl Study in Rural Areas of Kurdistan Province (West of Iran). 
Int J Pediatr, Vol.5, N.8, Serial No.44.

Mozurkewich EL, et al.,(2000). Working conditions and adverse pregnancy outcome: a meta-analysis. Obstet Gynecol, 95:623-34

Mudler. (2002). Prenatal maternal stress: effects on pregnancyand the (unborn) child. Early Human Development (70) 3-14

Niedhammer et al.,(2009). Occupational predictors of pregnancy outcomes in Irish working women in the Lifeways cohort. An International Journal of Obstetrics and Gynaecology on birth weight and other pregnancy outcomes. BJOG, 116:943-952

Rao S, et al.,(2003). Maternal activity in relation to birth size in rural India. The Pune Maternal Nutrition Study. European Journal of Clinical Nutrition. 57:531-542.

Rakers F, Bischoff S, Schiffner R, et al., (2015) Role of catecholamines in maternal-fetal stress transfer in sheep. Am J Obstet Gynecol 2015;213:684.e1-9..

Rego AS et al.,(2016). Physical activity in pregnancy and adverse birth outcomes. Cad. Saúde Pública, 32(11):e00086915

Saphiro,et al., (2013). Psychosocial stress in pregnancy and preterm birth: associations and mechanisms. $\mathbf{J}$ Perinat Med. 41(6): 631645.doi:10.1515/jpm-2012-0295.

Sharma S dan Mishra S. (2013). Maternal risk factors and consequences of low birth weight in Infants. IOSR Journal Of Humanities And Social Science (IOSR-JHSS), Volume 13, Issue 4.
Singh et al.,(2009). Maternal Factor for Low Birth Weight Babies. MJAFI, $65: 10-12$

$\mathrm{Su}$, et al., (2015). Maternal Stress in Gestation: Birth Outcomesand Stress-Related Hormone Response of theNeonates. Pediatrics and Neonatology 56, 376e381

Takito, Y M \& Helena, B.M. (2005). Maternal Posture And Its Influence On Birthweight. Rev Saúde Pública, 39 (3).

Takito, Y M \& Helena, B.M. (2010). Physical activity during pregnancy and fetal outcomes: A case-control study. Rev Saúde Pública, 44(1):90-101

UNICEF. (2016). Low Birtth Weight. https://data.unicef.org/topic/nutritio n/low-birthweight.

Watson E. Dorothy. (2016). Maternal Physical Activity: Influence On Maternal And Delivery Outcomes. (Thesis). Faculty of Health Sciences, University of the Witwatersrand.

World Health Organization (WHO) and United Nations Children's Fund (UNICEF). 2004. Low Birthweight: Country, Regional and Global Estimates. NewYork, NY: UNICEF

World Health Organization (WHO). 2014. Global Nutrition Targets 2025: Low Birth Weight Policy Brief. Geneva: World Health Organization

World Health Organization. 2016. Micronutrient supplementation in low-birth-weight and very-lowbirth-weight. 